$1-1-1959$

\title{
Foundation Plantings : Practices, Preferences and Needs of West Virginia Homeowners
}

Roger W. Pease

Follow this and additional works at: https://researchrepository.wvu.edu/ wv_agricultural_and_forestry_experiment_station_bulletins

\section{Digital Commons Citation}

Pease, Roger W., "Foundation Plantings : Practices, Preferences and Needs of West Virginia Homeowners" (1959). West Virginia Agricultural and Forestry Experiment Station Bulletins. 437.

https://researchrepository.wvu.edu/wv_agricultural_and_forestry_experiment_station_bulletins/414 @ WVU. It has been accepted for inclusion in West Virginia Agricultural and Forestry Experiment Station Bulletins by an authorized administrator of The Research Repository @ WVU. For more information, please contact ian.harmon@mail.wvu.edu. 


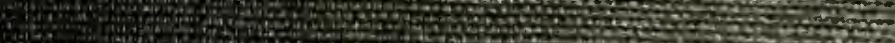

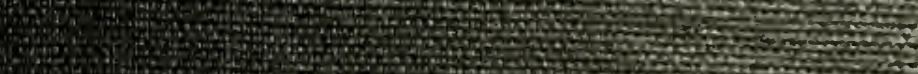

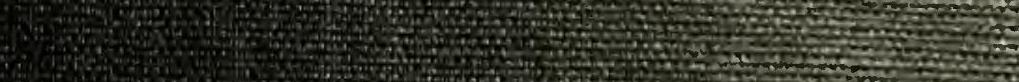
7'

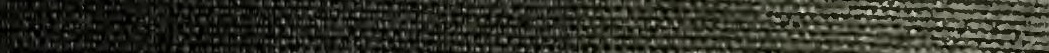
3.

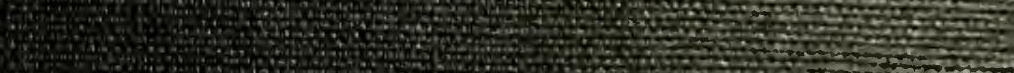

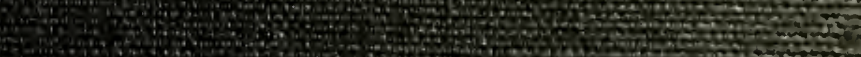

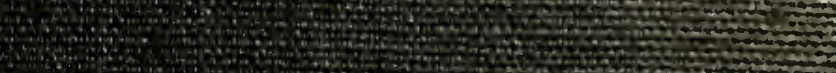

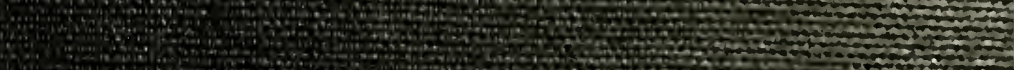

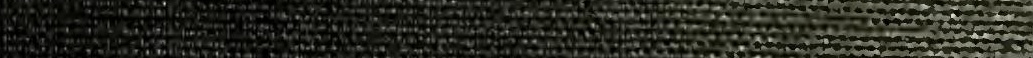

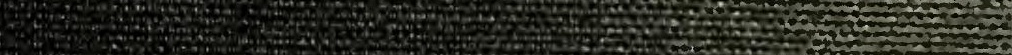

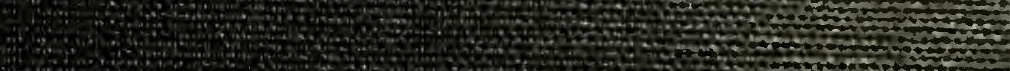
A

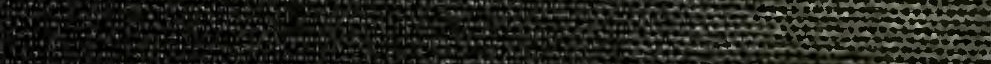
34 .

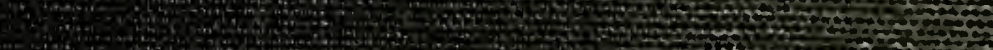

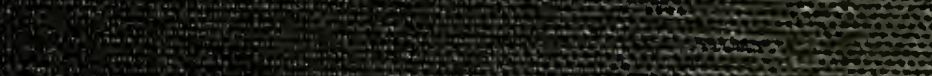

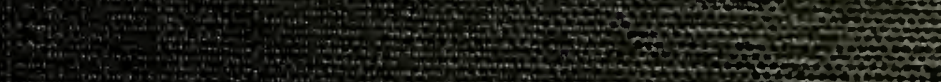
(...

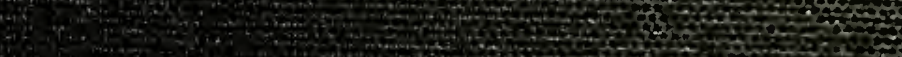

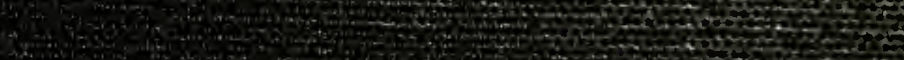
20.

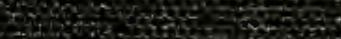

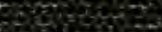

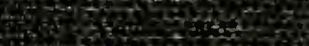

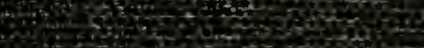

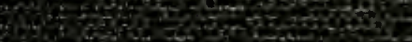

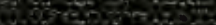

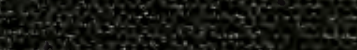

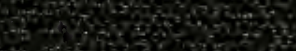

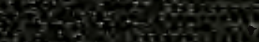
200 a

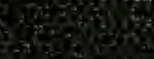
Q andiste

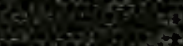

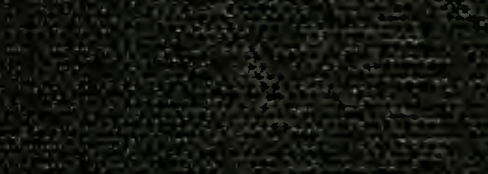
(4)

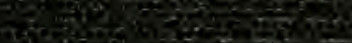

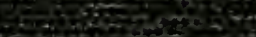

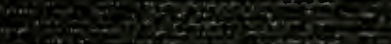

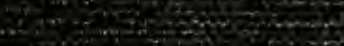

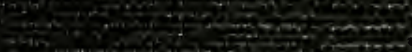

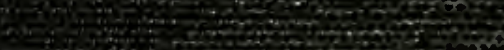

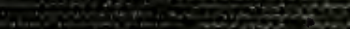


Digitized by the Internet Archive in 2010 with funding from . Lyrasis Members and Sloan Foundation 


\section{Foundation Plantings - -}

PRACTICES, PREEERENCES, AND

\section{NEEDS OF WEST VIRGINA HOMEOWNERS}

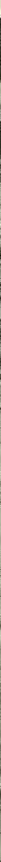




\title{
ACKNOWLEDGMENT
}

Appreciation is expressed to Patrick W. McClintic of Keyser, West Virginia, and to Lawrence H. Betler of Helvetia, West Virginia, who performed beyond the call of duty to complete this survey according to schedule. The cooperation of the West Virginia home-owner respondents to the questionnaire also is appreciated. ICover photograph by David R. Creel, Agricultural Experiment Station Photographer.)

\section{AUTHOR}

Roger W. Pease is Assistant Agricultural Economist in the West Virginia University Agricultural Experiment Station.

\author{
WEST VIRGinIA UNIVERSTT \\ Agricultural EXPlerimfent STATION \\ Collfge of Agriculturl, Forestry, and) Home Economics \\ A. H. VANLaniminghan, Director \\ MORGANTOWN
}

This bulletin is published as a contribution to the Northeast Regional marketing research project in ornamentals [NEM-15]. The West Virginia research was supported by both state and regional research funds. 


\section{Summary}

BOUT 90 per cent of West Virginia's non-farm homeowners maintain ornamental plantings close to the foundations of their homes. This estimate is based on a 1957 systematic sampling of 1,000 such homes (hroughout the State. Evergreens were more prevalent than deciduous plants, and the most numerous evergreens were junipers, yews, and arbor vitae. A poll of West Virginia plant specialists indicated that yew is the most desirable evergreen foundation plant within the State's less temperate areas, Japanese holly within the more temperate areas, and yew for State-ride use. The specialists all stated that spruce and white pine are unsatisfactory foundation plants.

There was no statistically significant relationship between any two of the following: homeowners' stated preferences, the plants used, and the plant specialists' desirability ratings.

About 60 per cent of the homeowners had purchased some ornamentals: 43 per cent entirely Irom West Virginia nurseries (or nursery garden centers), 1 per cent entirely from out-of-state sources, and about 16 per cent from both in-state and out-of-state concerns. Only about 6 per cent had purchased any ornamentals from West Virginia chain stores or from other in-state businesses handling plants as a sideline. About 24 per cent of the homeowners had used full-time-nursery planting services (in 1955 West Virginia full-time nurseries sold about 20 times as many ornamentals as part-time nurseries).

Crowded foundation plants, madequate shearing, homeowners' unfaniliarity with desirable evergreen species and with the standard grading system indicated that consumer-education services had been unarailable, or ineffective, or both.

There was a statistically significant relationship between the use of full-time-nursery planting services and the use ratio of the most desirable to the least desirable evergreens. No homeorners in 14 West Virginia county-seat towns (35 per cent of those surveyed) reported the use of lull-tine-nursery planting services, and within the same places only nine ( 14 per cent) of the homeowners reported the use of part-time nursery services. Among the homeowners interviered in the Eastern Panhandle area only about 5 per cent were able to identify, cither by name or location, a nursery whose planting services had been used. The State's relatively unserviced areas contained sufficient non-farm, orineroccupied hones to support several full-time nurseries, but no large concentrations of population (more than 20,000 residents) were within these areas. However, four comparatively isolated and small county-seat towns 
had been serviced extensively: one by a local wholesale nursery which conducted retail services as a sideline, and three by large retail nurseries as distant as 60 miles.

Foundation plantings around houses less than 50 years old had a significantly higher use ratio of desirable to undesirable evergreens than plantings around houses 50 years old and older. Owners of homes less than 50 years old also had used significantly more full-time-nursery planting services than had owners of older homes. The differences both in use-desirability ratio and in planting services performed were not significant between foundation plantings among house-age groups less than 10 years and 10 through 19 years old. When plantings were analyzed according to length of foundation facing a lawn, homes with the most extensive foundations bordering lawns had the significantly highest use ratio between desirable and undesirable evergreens, but such homes showed only a slight superiority in plant-service patronage. 


\section{Foundation Plantings - -}

\section{Practices, Preferences, and \\ Needs of West Virginia Homeowners}

\section{Introduction}

ROGER W. PEASE

N 1957 West Virginia University Agricultural Experiment Station personnel interviewed homeowners about their foundation plants. The purpose of the survey was to discover: first, relationships among consumer practices, consumer preferences, and the use of the most desirable ornamentals; second, where ornamentals are purchased; third, the effectiveness of educational services; and fourth, characteristics of the West Virginia market.

\section{Procedure}

The 1950 United States Census ${ }^{1}$ reported that there were 227,204 non-farm, owner-occupicd homes in West Virginia. To obtain data pertinent to the objectives of the study, a questionnaire was prepared for interviewing 1,000 of these non-farm, owner-occupants.

The State was divided into areas represented by either a countyseat town or a city with at least 20,000 residents. The number of questionnaires completed in each city or county seat was proportionate to the number of non-farm, owner-occupied homes in the area represented. By a systematic technique, respondents were selected from an alphabetized list. Homes were excluded from the survey if they had less than 8 feet of lawn between house and walk (or street). Any shrub or tree. whose trunk was within 6 feet of a house wall qualified as a foundation plant; and ground covers, roses, hedges, and flowers were not included in the data. After each interview, both foundation plants and lawn trees were inspected.

To obtain desirability ratings for the most common evergreen foundation plants, a short questionnaire was mailed to six academicallytrained plant specialists and to six nurserymen, all in West Virginia. The nurserymen had been landscape specialists for at least ten years or they employed full-time landscapers. Half of the respondents were located in

\footnotetext{
${ }^{1}$ All population data in this bulletin are based on the $1950 \mathrm{U}$, S. Census,
} 
the more temperate part of the State (including the Ohio Valley south of Wheeling), and half were in the less temperate part. They were asked to base their answers exclusively on beauty, growth habits, ${ }^{2}$ and hardiness of the plants involved. Ail responded to the questionnaire.

\section{Relationships Among Consumer Practices, Consumer Preferences, and the Use of the Most Desirable Evergreens}

The contrasts between consumer practice and preference concerning deciduous and evergreen foundation plants are indicated in Table 1. Only 12 per cent of the homeowners preferred deciduous plants, but 44 per cent of the foundation plants they used were deciduous. The ratio of preference between evergreen and deciduous plants was about 6 to 1 ; but the practice ratio was only about 1.3 to 1 . Either consumers had not chosen what they wanted, or the plants they wanted had not been available at acceptable prices.

Table 1. Consumer Practice and Preference Concerning Deciduous and Evergreen foundation Plants. (1,000 TVest Virginia

HOMEOWNERS, 1957)

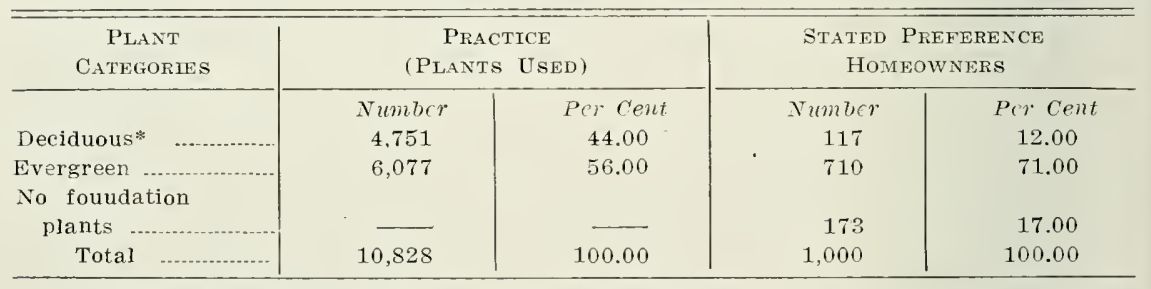

* All azaleas were classed as deciduous because, in much of West Virginia, the foliage of "evergreen" azaleas turns brown in the wint $r$.

Contradictions also existed between practice and preference concerning foundation plantings as such. Of the 88 homeowners who had no foundation plants, 52 ( 59 per cent) preferred to have them; of the 124 who preferred to have none, 71 (57 per cent) maintained plantings at the expense of considerable labor. In the latter case, owners could have achieved what they said they wanted more cheaply than they could maintain what they said they did not want.

The numbers of homeowners who preferred various categories of foundation plants are listed in Table 2. Spruce and white pine were grouped in one category because many respondents designated all native, narrow-leaved evergreen trees as "spruce" or "pine." Several species of spruce were used as foundation plants, but no pine trees other than

${ }^{2}$ Includes size at maturity, shape, density, response to shearing, and speed of growth. 
Table 2. Homeowners' Preferences Concerning Various Categorits of Foundation Plants. (1,000 West Virginia Respondents, 1957)

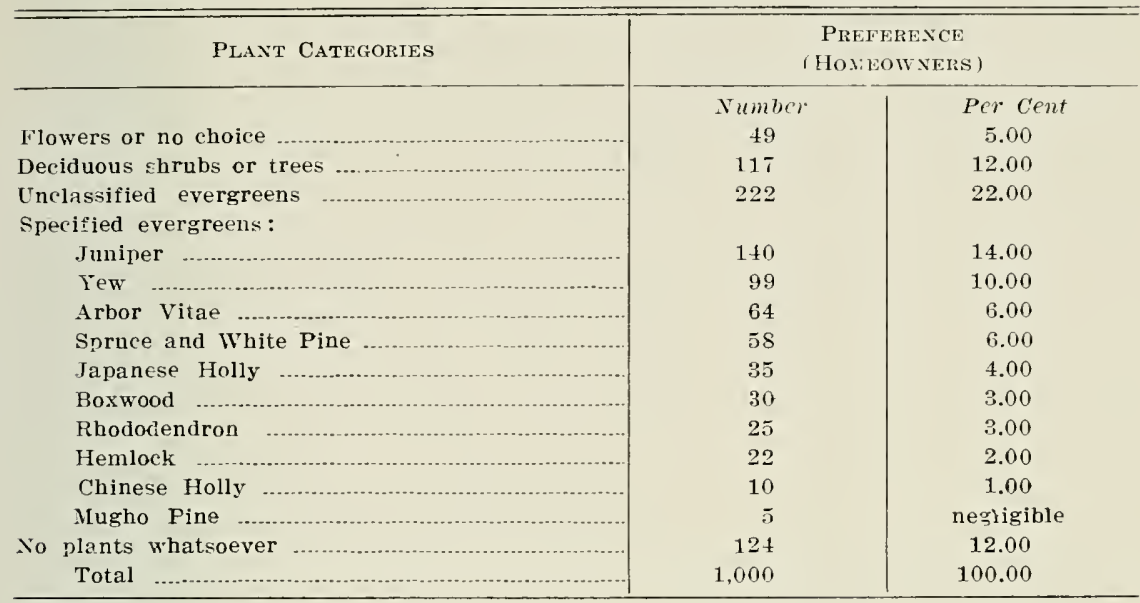

white pine were reported (mugho pine is classed as a shrub). Of the 710 homeowners who preferred evergreens, 222 were unable to select any one type. Evidently many respondents either could not differentiate among evergreen foundation plants or believed that the differences among evergreens are negligible.

The volumes and proportions of evergreens used as foundation plants are shown in Table 3. Junipes, arbor vitae, yew, hemlock, sprucewhite pine, and Japanese holly comprised about 78 per cent of the total volume. About 22 per cent of all the evergreens used were junipers.

\section{Table 3. The Volumes and Proportions of Various Categories of Evergreen Ornamentals Used By 1,000 West Virginia}

HOMEOWNERS, 1957

\begin{tabular}{|c|c|c|}
\hline Plant Categortes & Volume & $\begin{array}{l}\text { Proportion of Ali } \\
\text { Evtrareens Used }\end{array}$ \\
\hline Juniper & $\begin{array}{c}\text { Numbrr } \\
1,313\end{array}$ & $\begin{array}{c}P e r \\
2 C n t \\
22\end{array}$ \\
\hline Arbor Vitae & 961 & 16 \\
\hline Yew & 895 & 14 \\
\hline Heinlock & :19 & 10 \\
\hline 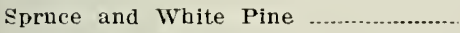 & \pm 76 & $\mathrm{~s}$ \\
\hline 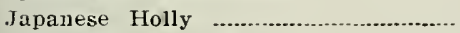 & 471 & $\mathrm{~s}$ \\
\hline Unclassified evergreens & 431 & 7 \\
\hline Boxwood & 421 & $\tau$ \\
\hline Rhododendron & 364 & 6 \\
\hline Chinese Holly & 97 & 2 \\
\hline 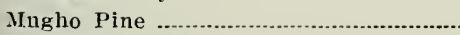 & 29 & negligible \\
\hline Total & 6,077 & 100.00 \\
\hline
\end{tabular}


Results of the 12 specialists' votes on desirability are shown in Table 4. For the more temperate area of the State Japanese holly was selected among all evergreens as the most desirable (four among a total of six votes); yew was in second place, with two votes. For the less temperate area, yew was selected as the most desirable (four among a total of six votes); Japanese holly and juniper were in second place, each with one vote. For State-wide use yew was selected (five among a total of 12 votes); Japanese holly and juniper were in second place, each with three votes. No other evergreen was selected. The concensus among the specialists was that arbor vitae has a definite use as a relatively inexpensive foundation plant, that hemlock occasionally is suitable (if closely sheared), but that spruce and white pine never should be used as foundation plants.

Table 4. Evergreen Foundation Plant Selegtions, Exclusions, ani Ratings. Poll of 12 West Virginia Spegialists, 1957

\begin{tabular}{|c|c|c|c|c|c|c|c|}
\hline \multirow[b]{2}{*}{ CATEGORIES } & \multicolumn{7}{|c|}{ Selections and Eixclusions among EvergReENS (Votes)* } \\
\hline & $\mathrm{Y} \pm W$ & $\begin{array}{l}\text { JAPANESE } \\
\text { HoLLYY }\end{array}$ & JUNIPER & $\begin{array}{l}\text { ARBOR } \\
\text { VItAe }\end{array}$ & HEMLOCK & SPRUCE & $\begin{array}{c}\text { White } \\
\text { PINE }\end{array}$ \\
\hline $\begin{array}{l}\text { Best in more } \\
\text { temperate area } \\
\text { (Six votes) }\end{array}$ & $\begin{array}{c}\text { Number } \\
2\end{array}$ & Number & Number & Number & Number & - & - \\
\hline $\begin{array}{l}\text { Best in less } \\
\text { temperate area } \\
\text { (Six votes) }\end{array}$ & 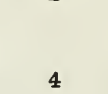 & 1. & 1 & — & - & - & - \\
\hline Best State-wide & & & & & & & \\
\hline $\begin{array}{l}\text { (12 votes) } \\
\text { Never to be used }\end{array}$ & $5^{* *}$ & 3 & 3 & 一 & 一 & $\overrightarrow{10}$ & 一 \\
\hline Never to be used & 一 & - & - & - & 2 & 12 & 12 \\
\hline $\begin{array}{l}\text { Total selection } \\
\text { (Positive votes) } \\
\text { Total exclusion }\end{array}$ & +11 & +8 & +4 & - & - & 一 & - \\
\hline (Negative votes) & - & - & - & $\longrightarrow$ & -2 & -12 & -12 \\
\hline $\begin{array}{l}\text { Ratings based on } \\
\text { total votes }\end{array}$ & 1 & 2 & 3 & 4 & $\mathbf{5}$ & 6 & 6 \\
\hline
\end{tabular}

* Fach specialist voted both for best plant in his area and best plant for State-wide use. Thus there were 6 votes for best in each area but 12 votes for best for State-wide use.

**One plant specialist refrained from voting in this category.

Table 5 indicates the relationship among practice, preference, and use-desirability ratings for the six most common evergreen foundation plants. In more than one time in twenty an equal degree of relationship might occur by chance. When practice ratings were analyzed, first against preference ratings and second against use-desirability ratings, both relationships were found to be statistically non-significant. The analyses indicate that practice, preference, and use-desirability of evergreen foundation plants tended to operate independently. ${ }^{3}$

${ }^{3}$ G. W. Snedecor, Statistical Methods, Fifth Wdition, pp. 190-191. The rank correlations were $0.429,0.772,0.336(0.886$ needed to indicate significance on the 5 per cent Ievel). 
Table 5. The Relationship Among Practice, Preferenge, and DeSirability Ratings for the Most Common Evergreen Foundation Plants. (1,000 West Virginia Homeowners, 1957)

\begin{tabular}{|c|c|c|c|c|c|}
\hline \multirow{2}{*}{$\begin{array}{c}\text { Plant } \\
\text { CATEGORIES }\end{array}$} & \multicolumn{2}{|c|}{ Practice } & \multicolumn{2}{|c|}{ Preference } & \multirow{2}{*}{$\frac{\text { DESIRABILITY }}{\text { RANK }}$} \\
\hline & $\begin{array}{c}\text { Plantis } \\
\text { Used }\end{array}$ & RANK & $\begin{array}{l}\text { HOME- } \\
\text { OWNERS }\end{array}$ & RANK & \\
\hline & Number & & Number & & \\
\hline Juniper & 1,313 & 1 & 140 & 1 & 3 \\
\hline Arbor Vitae .................... & 961 & 2 & 64 & 3 & 4 \\
\hline Yew & 895 & 3 & 99 & 2 & 1 \\
\hline Hemlock & 619 & 4 & 0 & 6 & 5 \\
\hline Spruce - White Pine .... & 476 & 5 & 58 & 4 & 6 \\
\hline Japanese Holly ........... & 471 & 6 & 35 & 5 & 2 \\
\hline
\end{tabular}

\section{Where Ornamentals are Purchased}

Among the 1,000 homeowners interviewed, 912 maintained foundation plants. Among the latter, 597 reported that they had procured all or part of their foundation plants, and 315 reported that the homes they had purchased already had been landscaped and therefore these homeowners had made no purchases of ornamentals. Only 62 respondents had bought ornamentals from West Virginia stores which offered plants as a side line; but 167 had made some out-of-state purchases. Eleven homeowners had purchased ornamentals only from out-of-state, 430 had purchased only from in-state, and 156 had purchased from both in-state and out-of-state sources. Full-time-nursery planting services had been used by 242 homeowners. In a previous study it was reported that full-time nurseries sold about 20 times as many ornamentals as part-time nurseries. ${ }^{4}$ These data indicate that, in 1957, West Virginia nurserymen were losing much more trade to out-of-state concerns than to in-state stores carrying ornamentals as a side line.

Other respondents, who had owned their homes for ten years or more, could not remember how many plants of any species they had purchased. About 99 per cent of the respondents reported that they had obtained no foundation plants from the wild, but the presence of flame azalea and native rhododendron indicated that some responses were inaccurate or that previous owners had obtained the plants from the wild or from peddlers. Both plant species grow wild in the State and seldom are raised by West Virginia nurserymen. It also was difficult for many homeowners to report accurately how many of their purchased ornamentals had died or had been replaced. Typical responses were

${ }^{4}$ Roger W. Pease, Some Effects of Location on West Virginia Nurseries Marketing! Ornamental Plants. W. Va. Univ. Agr. Exp. Sta. Bul. 394, Feb. 1957, p. 5. 
"very few" and "not many." For these reasons analyses were not made of data pertaining to number of specific plants purchased, plants obtained. from the wild, and replacements for dead plants.

\section{The Effectiveness of Educational Services}

Crowding was evident in lawn or house plantings among 85 per cent of the homes with foundation plants (791 among 912). The crowns of shade trees less than 20 feet apart were competing; flowering trees had been planted less than 12 feet apart; and in about 83 per cent of the plantings (765 among 912) unsheared shrubs obscured one or more windows. The trunks of about 74 per cent of the foundation plants used were less than 21/2 feet from the house walls. As indicated in Table 2, 222 respondents preferred evergrecus but apparently were unable to choose one kind. If the same unfamiliarity proportion existed concern. ing deciduous plants, approximately 34 per cent (339) of the respondents may have been too uninformed to select species suited to base planting. Only 1 per cent of the respondents $(10$ among 1,000$)$ showed a rudimentary knowledge of the industry's standard grading system ${ }^{5}$ by checking on a card what is meant by an 18- to 24-inch evergreen shrub. Judged on the bases of plant spacing, shearing, familiarity with plant species, and knowledge of the grading system, educational services supplied by nurserymen and by plant specialists had been unavailable or ineffective among the homeowners interviewed.

However, there is evidence that nurserymen, through personal contacts do influence the practice of homeowners. Full-time nurserymen had supplied and set foundation plants (often only a few) for 242 of the homeowners and in so doing apparently had performed effective edıcational services. Nursery planting services were accompanied by an increased selection of the most desirable evergreen foundation plants and by a reduction of the least desirable (Table 6). The use ratio of the most desirable to the least desirable evergreens was about 7 to 1 where homeowners had employed full-time-nursery planting services; where owners had used other planting services (including their own) the ratio was about 1.2 to 1 ; and where no purchase had been made thr ratio was about 2.3 to 1 . These differences among ratios were statistically highly significant; ${ }^{6}$ and the probability that they had happened by chance was negligible. The difference was especially great between plantings where full-time-nursery services had been used and plantings where other

\footnotetext{
"The American Association of Nurserymen has adopted a grading system used extensively by nurserymen.

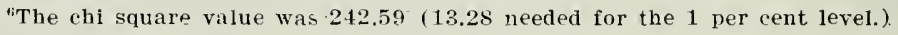


Table 6. The Relationship Betweey Full-Time-Nursery Planting Services and the Use of thl: Most 1)esirable ani Least Desirable Evergreens. (1,000 West Virginia Honeowners, 1957)

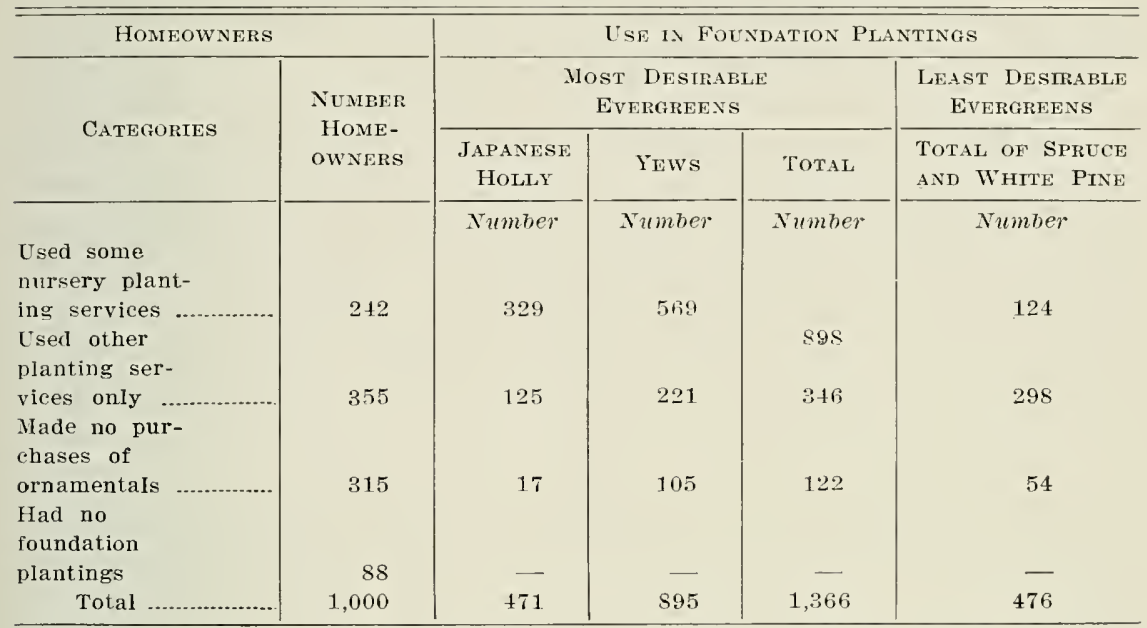

services had been used. Apparently patronage of full-time-nursery planting services had improved the quality of plantings, but the use of other planting services had lowered quality. "Do-it-yourself" planting may have caused the low desirability ratio of evergreens in the latter category.

In six (15 per cent) of the cities surveyed more than one-third of the homeowners interviewed had used planting services from full-time nurseries. Table 7 shows, within these cities, median incomes, populations, and the proportions of homes which used full-time-nursery

Table 7. Median Income, Population, and Proportion of OtnnerOccupied Homes Using Full-Time-Nursery Services. (The Six West Virginia Cities with the Largest Proportions of Serviced Homes, 1957)

\begin{tabular}{|c|c|c|c|}
\hline City* & $\begin{array}{l}\text { MEDLAN } \\
\text { INCOMES }\end{array}$ & Population & $\begin{array}{l}\text { PROPORTION OF } \\
\text { SERVICED HOMES }\end{array}$ \\
\hline …… & $\begin{array}{c}\text { Dollars } \\
2.940\end{array}$ & $\begin{array}{c}\text { Number } \\
5,079\end{array}$ & $\begin{array}{c}\text { Per Cent } \\
47.83\end{array}$ \\
\hline Bluefield & 2,572 & 21,506 & 45.24 \\
\hline Sumnersville* $+\ldots$ & 2,300 & 1,625 & 41.67 \\
\hline Lewisburg** & 2.235 & 2,192 & 38.89 \\
\hline Charleston & 3,232 & 73.501 & $8+.97$ \\
\hline Madison & 2,528 & 2.025 & 33.33 \\
\hline
\end{tabular}

* The only cities where one-third or more of the homeowners interviewed had used scme full-time nursery services.

* The U. S. Census of 1950 recorded median incomes of females and unrelated individuals for places whose populations exceeded 9,999: otherwise this catum was recorded for counties only. Populations in Summersville, Lewisburg, and Madison were less than 10,000 each, and in Table 5 their median incomes are reported on the basis of their respective counties. 
planting services. The data indicate that population and the proportion of serviced homes varied independently among the cities. Charleston, with a population of 73,051, ranked fifth in proportion of homes serviced; but Bluefield, population 21,506, ranked second. Factors other than population concentration must have caused the planting service variations among the six cities. For purposes of analysis the median incomes were arranged in three categories: more than $\$ 3,000$, $\$ 2,500-2,999$, and $\$ 2,000-2,499$. An analysis was made of the numbers of serviced and unserviced homes within these three categories. No significant differences existed among the three categories (nor between any two), for similar differences might have happened by chance in more than one-in-twenty cases. ${ }^{\top}$ Thus the cities' median incomes, as well as their populations, were unrelated to proportions of planting services performed.

Logan, Summersville, and Madison, with relatively low concentrations of population, were more than 30 miles from any full-time nursery: about 50, 40, and 35 miles, respectively. However, in Logan few services from the nearest full-time nursery were reported, but two large concerns, both more than 60 miles distant, had performed about 80 per cent of the services reported in the city. In Summersville, one nursery about 40 miles distant (by hard-surface road) had performed all of the services. In Madison, two large concerns, from distances of about 35 and 58 miles respectively, had performed all of the services attributed to full-time concerns. Evidently well-landscaped homes spread their influence rapidly in small towns, and certain nurseries consider it profitable to service such places from distances as great as 60 miles.

In Bluefield and Charleston, large local concerns, specializing in landscaping, had supplied most of the services reported; but there were lour other competing concerns near Bluefield and five others in Charleston. Keen competition and the availability of specialized landscape services may explain the relatively large proportion of Bluefield and Charleston homes which used full-time-nursery planting services.

In Lewisburg, one wholesale-retail nursery, subsidiary to a large, out-of-state concern, performed all of the services. This nursery's retail sales were supplementary to its wholesale business and were relatively small. In 1950 no city with a population greater than 6,000 persons was within 60 miles of Lewisburg.

The analysis indicates that there were various causal factors for the large proportions of planting services used in the six cities studied. In

${ }^{7}$ The chi square value for analysis among all categories was 2.39 (5.99 needed for the 5 per cent level); between categories, chi square values were 2.36, 0.27 , and 0.31 ( 3.84 needed for the 5 per cent level). 
Tarle 9. The Usi: of Full-Time-Nursery Planting Serviges and the Presenci of the Most Desirable and Least Desirable Evergreen Foundation Plants, Related to Length of House Foundations Facing Eight Feet or More of LAWN. (1,000 West Virginia

Owner-Occupied Hoires, 195̄

\begin{tabular}{|c|c|c|c|c|c|}
\hline \multirow{2}{*}{$\begin{array}{c}\text { LENGTH OF } \\
\text { FOUNDATION } \\
\text { FACING } 8 \text { FEET OR } \\
\text { MORE OF LAWN }\end{array}$} & \multirow[b]{2}{*}{ HOMES } & \multirow{2}{*}{\multicolumn{2}{|c|}{$\begin{array}{c}\text { OWNERS USING } \\
\text { SERVICES }\end{array}$}} & \multicolumn{2}{|c|}{ Evergreen Plants Used } \\
\hline & & & & $\begin{array}{c}\text { Most DESIRABLE } \\
\text { (JAPANESE HOLLY } \\
\text { AND YEW) }\end{array}$ & $\begin{array}{c}\text { LEAST DESIRABLE } \\
\text { (SPRUCE AND } \\
\text { WhITE PINE) }\end{array}$ \\
\hline & Number & Number & Per Cent & Number & Number \\
\hline $\begin{array}{l}\text { Less than } \\
50 \text { feet }\end{array}$ & 182 & 29 & 16 & 79 & 40 \\
\hline $50-89$ feet ............. & 328 & 78 & 24 & 306 & 146 \\
\hline 90 feet & & & & & \\
\hline 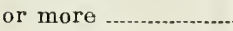 & 490 & 135 & 28 & 981 & 290 \\
\hline Total & 1,000 & 242 & 一 & 1,366 & 476 \\
\hline
\end{tabular}

In Table 9 the perlormance of full-time-nursery planting services and the use of the most desirable and least desirable evergreen foundation plants are related to lawn areas adjacent to house foundations. Homes within group one had less than 50 linear feet of house foundation bordering lawns ( 8 feet or more in depth); within group two, 50 through 89 feet of foundation bordered lawns; and within group three, 90 or more feet of foundation faced lawns. Planting-service patronage was significantly less among group one (smallest lawn border) than among either of the other two groups, ${ }^{10}$ but between the two larger-lawn-border groups the service patronage difference was not significant. ${ }^{11}$ Use-desirability ratios were significantly greater among group three (largest lawn border) than among either of the other two groups ${ }^{12}$ but were non-significant between groups one and two. ${ }^{13}$

Evidently murserymen exert the most plant-selection influence whein they service houses with extensive larn borders. The most desirable evergreens are relatively high-cost items. Probably owners of houses facing extensive lawn borders are least willing to reduce cost by sacrificing plant desirability. There may be a closer correlation between lawn border and owner income than between house age and owner income; and owner income may be a determining factor in the selection of the most desirable evergreen foundatien plants.

"When the numbers of homeowners nsing scrvices abd not using services were tested, the chi square values were 4.34 and 9.71 (3.84 needed to show significance at the 5 per cent level).

${ }^{11}$ The chi square value was 1.50 (3.S4 needed for the 5 per cent level).

${ }^{12}$ The chi square values were 7.01 and 8.75 when 6.63 was needed for the 1 per cent level.

${ }^{13}$ The chi square value was 0.07 when 3.84 was ueeded for the 5 per cent level. 


\section{Some Characteristics of the West Virginia Market}

No homeowners reported the use of full-time-nursery planting services in 14 ( 35 per cent) of the representative towns surveyed, and no full-time nurseries were within the areas represented. In the same areas, part-time nursery planting services had been reported by only nine (14 per cent) of the homeowners. A total of 15,732 non-farm, owneroccupied homes were within the areas involved, but the homes were relatively scattered. None of the county-seat towns involved had more than 10,000 residents and only three had more than 6,000. However, in the two counties (population 94,196) represented by Bluefield (population 21,506) only 11,751 homeowners were serviced by five full-time nurseries. The scattered population within the unserviced areas may have been the causal factor for the absence of both nurseries and planting services.

Although unserviced areas offer especial opportunities to part-time nurseries, in 1955 half of West Virginia's part-time concerns sold less than 64 plants per nursery. ${ }^{14}$ Inadequate shearing, undesirable varieties, and weed-infested growing areas were characteristic of part-time concerns. The seasonal demands involved in growing and retailing ornamentals had created labor problems. However, some part-time concerns were successful. One operator who worked full-time in a nearby city maintained a thriving part-time nursery. The growing area was weed-free, desirable species predominated, and the plants were well-formed and healthy. No planting services were performed, and the nursery was open for sales only in the evening. Seasonal customers, even from out-of-state, kept two men busy digging plants to orcier until late dusk. All labor was performed on a part-time basis. Similar concerns might thrive on "drive-in" patronage, even in areas with scattered populations.

${ }^{14}$ Roger W. Pease, Op. Cit., p. 5. 


